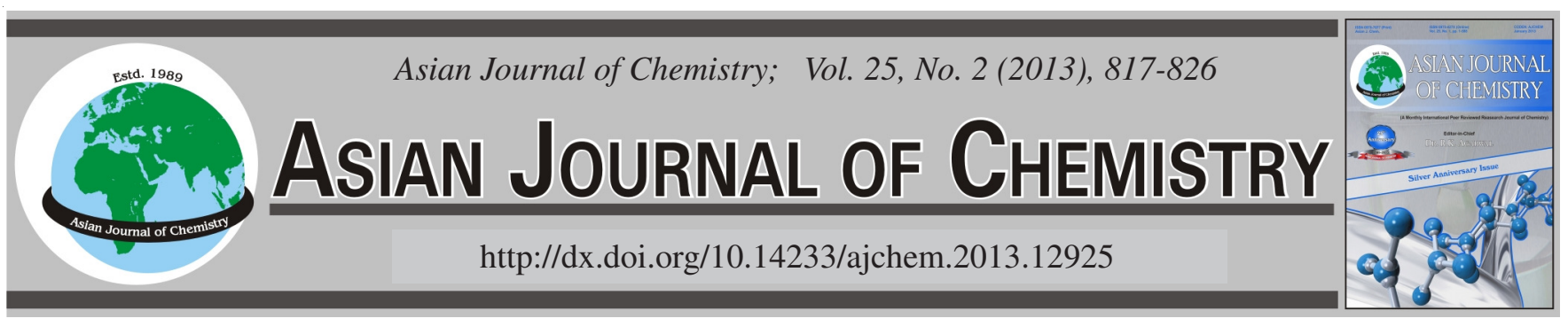

\title{
Artificial Neural Network, Equilibrium, Kinetics and Thermodynamics Modeling of Reactive Orange 12 Dye Using Rice Husk
}

\author{
A.M. Ghaedi ${ }^{*}$, A. Vafaei, S. Hafezi and M. Mohagheghian
}

Department of Applied Chemistry, Gachsaran Branch, Islamic Azad University, P.O. Box 75818-63876, Gachsaran, Iran

*Corresponding author: Tel: +98 742 333459; Fax: +98 742 3332003; E-mail: abm_ghaedi@yahoo.com

\begin{abstract}
The aim of this work was to study artificial neural network (ANN), equilibrium, kinetics, mechanism modeling of reactive orange 12 using rice husk. A batch system was employed for all experiments. The optimum operating conditions for adsorption reactive orange 12 dye using rice husk were $3 \mathrm{~g}$ adsorbent dose, $150 \mu \mathrm{m}$ particle size, $10 \mathrm{mg} / \mathrm{L}$ initial concentration of dye, $2 \mathrm{~h}$ contact time, $35^{\circ} \mathrm{C}$ temperature and $\mathrm{pH}$ 3. A three layer back propagation artificial neural network (BP-ANN) model with a tangent sigmoid function (tansig) at hidden layer with 10 neurons, a linear transfer function (pureline) at output layer and the Levenberg-Marquardt algorithm (LMA) was used to predict the adsorption efficiency (\%) of reactive orange 12 using rice husk. The optimal ANN model was found with a minimum mean square error (MSE) of 0.00011 and a determination coefficient $\left(\mathrm{R}^{2}\right)$ of $c a .0 .966$ between the network outputs and experimental data. Langmuir isotherm was found to be optimum isotherm $\left(\mathrm{R}^{2}=0.993\right)$ as compared with Freundlich, Temkin and Dubinin-Radushkevich $(D-R)$ isotherms. The pseudo second order model $\left(R^{2}=0.9993\right)$ affected the kinetics better than pseudo first order model $\left(R^{2}=0.9652\right)$. The positive value of $\Delta \mathrm{H}^{\circ}(32.94 \mathrm{~J} / \mathrm{mol})$ displays the endothermic adsorption. The rate of adsorption was controlled by both boundary layer and pore diffusion. Coefficient of pore diffusion $\left(\mathrm{D}=1.23 \times 10^{-8} \mathrm{~cm}^{2} / \mathrm{s}\right)$ confirms the boundary layer diffusion (mass transfer) as the controlling step in the dye adsorption process.
\end{abstract}

Key Words: Adsorption, Reactive orange 12, Rice husk, Artificial neural network.

\section{INTRODUCTION}

The discharge of dyes is a worldwide environmental problem. These dyes are widely applied in industries namely dyestuff, rubber, paper, leather, textiles, plastics and cosmetics ${ }^{1-3}$. Reactive azo dyes are highly soluble in water and differ from all other categories of dyes in which they bind to the textile fibers namely cotton, wool and silk to form covalent bonds ${ }^{4}$. They have the favorable features, such as simplification dyeing process, bright colours and improvement fastness ${ }^{5}$. Reactive azo are the group of dyes most widely applied industrially. However, they have disadvantages namely hydrolysis accompanies fixation (resulting in waste of dye and extra wash step), coloured effluent discharge processing and large amount of electrolytes used; therefore, they are released in the wastewater ${ }^{6}$. These dyes are toxic, carcinogenic and mutagenic. In addition, the human eye can recognize low concentration of reactive azo dye in water. Therefore, the presence of these dyes in the environment would not be permitted on aesthetic grounds ${ }^{7,8}$. Thus, the removal of these dyes from wastewater is a great importance $e^{9-15}$.

There are several methods to remove colour from industrial effluents. Torres and Gutierrez categorized these methods in four main classes including (i) oxidation techniques (electrochemical oxidation, peroxides, ozone, etc.); (ii) physicochemical techniques (adsorption, ion exchange and coagulation/ flocculation); (iii) membranes (reverse osmosis, nanofiltration, etc.) and (iv) biologic techniques (enzymatic decolourization processes $)^{16}$.

The physical adsorption has been found to be a robust method for decolourization of the waste effluent. But this method is limited by high cost of adsorbents. Besides, there is an increasing tendency in searching for low cost adsorbent matters for the adsorption of colours namely rice husk, coir pith, sugar cane dust, sawdust, activated carbon fibers, fly ash and shale oil ash ${ }^{4}$. Rice husk is a main waste product of the rice milling industry in many countries such as Iran. Some authors have used the rice husk as an adsorbent for the colour removal from waste effluent ${ }^{17-20}$.

The artificial neural network (ANN), which has been recognized as a powerful tool capable of performing better than conventional mathematical models particularly for the case of nonlinear and multiple processing systems, is one of the extensively studied areas within artificial intelligence. The ANN is stimulated by biological model and the building blocks 
are neurons that are combined into layers. The input is received and weighed according to weighting factors and the resulting quantities are summed up. Without prior and detailed knowledge of the relationship between processing variables, ANN could relate the input to output parameters learning from the provided example and adapting itself through the learning stage $^{21}$. Compared to empirical models, ANN is considered to be more advantageous because it is powerful to noise and can accommodate multiple-input and multiple-output systems. In most cases it has been elucidated that ANN models can carry out better than the conventional ones based on regression, statistical or parametric models. However, a few works have been done to apply ANN models in adsorption ${ }^{22,23}$.

The aim of this investigation is to use rice husk for removal of reactive orange 12 (RO 12) from aqueous solution. The influence of various experimental factors namely adsorbent amount, $\mathrm{pH}$, dye concentration, contact time and temperature on reactive orange 12 adsorption was studied. On the basis of experiments, a three layer ANN model using a back propagation (BP) algorithm to predict removal of the reactive orange 12 dye by rice husk were proposed. Then, outputs obtained from the ANN modeling were compared with empirical data. Finally, adsorption equilibriums and kinetics of the sorption process were investigated and various thermodynamic parameters were obtained.

\section{EXPERIMENTAL}

Rice husk was obtained from Fars province in Iran. Sodium hydroxide, hydrochloric acid and sulfuric acid were provided by Merck (Germany). Deionized water was used for solution preparation. Reactive orange (RO 12) (Fig. 1) dye $\left(\mathrm{C}_{20} \mathrm{H}_{13} \mathrm{~N}_{9} \mathrm{O}_{10} \mathrm{~S}_{3} \mathrm{Cl} \cdot 3 \mathrm{Na}\right)$ was provided from Pishrane Tabriz (Iran) and was used without further purification.<smiles>NC(=O)Nc1cc(Nc2nc(N)nc(Cl)n2)ccc1/N=N/C1C=C2C(=CC1S(=O)(=O)O)CC(S(=O)(=O)O[Na])C=C2C(N)([O])O</smiles>

Fig. 1. Chemical structure of reactive orange 12 dye

Preparation of adsorbent: Rice husk were collected from a local rice milling industry, boiled with dilute hydrochloric acid for $0.5 \mathrm{~h}$ and continuously washed with distilled water to remove the surface adhered particles and water soluble materials and then dried at a temperature of $60-80^{\circ} \mathrm{C}$ in electric oven. Acid hydrolyzed rice husk was finally sieved and particle sizes of 149,250 and $400 \mu \mathrm{m}$ were obtained.

Determination of concentration of dye solutions: The stock solution of dye $(1000 \mathrm{mg} / \mathrm{L})$ was prepared in water. The others aqueous solutions were made by appropriate dilution of stock solution. The concentration of dye aqueous solutions $(\mathrm{mg} / \mathrm{L})$ was calculated at $\lambda_{\max }=417 \mathrm{~nm}$ using the calibration curve standard $\left(\mathrm{R}^{2}=0.999\right)$ with a $1.0 \mathrm{~cm}$ light path quartz cells using a UV-visible spectrophotometer (Lambda Bio 25, Perkin Elmer, USA).
Batch sorption studies: For all experiments, a batch adsorption system was performed at room temperature $(25 \pm$ $1{ }^{\circ} \mathrm{C}$ ). Solution $\mathrm{pH}$ was adjusted with dilute $\mathrm{H}_{2} \mathrm{SO}_{4}$ or $\mathrm{NaOH}$ solution. A known dose of absorbent was added to samples and was agitated. After allowing adequate time for adsorption equilibrium, the mixtures were filtered and the concentration of dyes was determined in the filtrate. The percentage removal of dye was calculated using following relationship:

$$
\operatorname{Removal}(\%)=\frac{\left(\mathrm{C}_{0}-\mathrm{C}_{\mathrm{t}}\right)}{\mathrm{C}_{0}} \times 100
$$

where, $\mathrm{C}_{0}$ and $\mathrm{C}_{\mathrm{t}}(\mathrm{mg} / \mathrm{L})$ are the dye concentration at initial and any time, respectively.

The influence of various factors on the adsorption process was observed by varying initial $\mathrm{pH}$ of solution $(3,5,7,9,11)$, adsorbent dose, $\mathrm{W}(0.5,1,1.5,2.0,2.5$ and $3.0 \mathrm{~g} / \mathrm{L})$, contact time, $\mathrm{t}(30,60,90,120,13,150,175$ and $180 \mathrm{~min})$, initial dye concentration, $\mathrm{C}_{0}(10,20,30,40,50,60$ and $70 \mathrm{mg} / \mathrm{L})$, particle sizes adsorbent, $S(149,250$ and $400 \mu \mathrm{m})$ and temperature $\left(25,35,45,55\right.$ and $\left.65^{\circ} \mathrm{C}\right)$. The solution volume (V) was kept constant $(50 \mathrm{~mL})$.

Artificial neural network: To predict the efficiency of adsorption, Neural Network Toolbox of MATLAB mathematical software was utilized. As indicated in Fig. 2, a three layer ANN with Levenberg-Marquardt (LM) back propagation, tangent sigmoid transfer function (tansig) at hidden layer and a linear transfer function (purelin) at output layer were applied. Before starting the training process all the ANN inputs and outputs were normalized to locate in the range of 0 to 1 using the corresponding maximum value to maintain the explanation of the weights and restrain numerical overflows. The normalization was calculated by using the relationship as offered below ${ }^{24}$ :

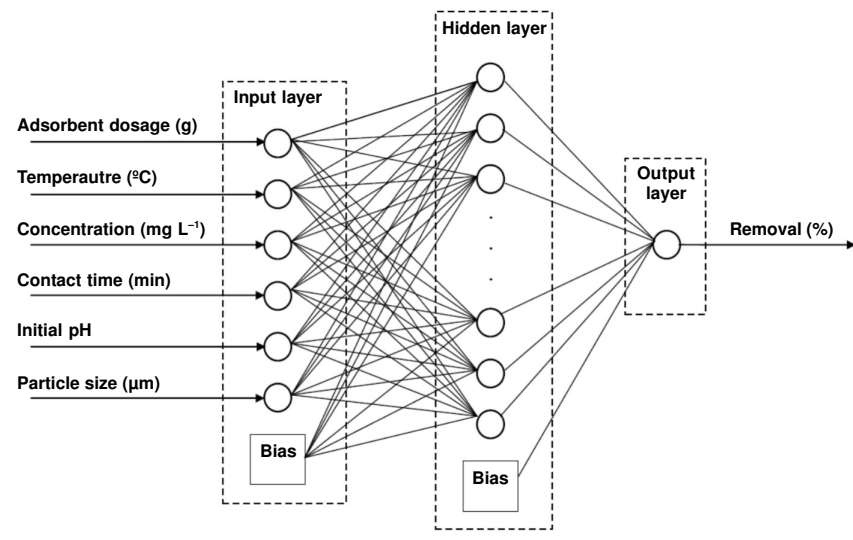

Fig. 2. Structure of a three layer BP-ANN for the prediction of the adsorption efficiency

$$
\mathrm{x}_{\mathrm{i}}^{\prime}=\frac{\mathrm{x}_{\mathrm{i}}}{\mathrm{X}_{\max }}
$$

where, $\mathrm{x}_{\mathrm{i}}^{\prime}$ is the normalized value, $\mathrm{x}_{\mathrm{i}}$ the original data and $\mathrm{x}_{\max }$ the maximum value.

Training was done for trial configuration of each number of hidden units in order to find the optimum neuron numbers in hidden layer that produced the minimum error. To avoid the potential problems and over-fitting or memorization while 
employing the back propagation algorithm two common methods were used. These were (i) early stopping and (ii) minimizing the number of hidden units ${ }^{25}$. The available database was split into three partitions. The first partition was used to carry out the training of network $(70 \%)$. The second partition $(15 \%)$ of the database was used to estimate the quality of the network during training. In order to evaluate the performance of trained network on new database, the third test partition (15\%) was used. The training process was accomplished until a minimum of the error was reached in the second (validation) partition. The estimation of the performance of the trained network was based on the accuracy of the network on the test partition. The networks were trained for a fixed number of 1000 cycles. To obtain the optimum model, several topologies of ANN were evaluated and in each step the mean square error (MSE) was figured. Furthermore, the coefficient of determination $\left(\mathrm{R}^{2}\right)$ of the linear regression line between the predicted value from the ANN model and the desired were calculated. Error measures used to compare the performance of various ANN models were as follows:

$$
\begin{aligned}
\text { MSE } & =\frac{1}{\mathrm{~N}} \sum_{\mathrm{i}=1}^{\mathrm{N}}\left(\left|\mathrm{y}_{\mathrm{prd}, \mathrm{i}}-\mathrm{y}_{\text {exp }, \mathrm{i}}\right|\right)^{2} \\
\mathrm{R}^{2} & =1-\frac{\sum_{\mathrm{i}=1}^{\mathrm{N}}\left(\mathrm{y}_{\mathrm{prd}, \mathrm{i}}-\mathrm{y}_{\text {exp }, \mathrm{i}}\right)}{\sum_{\mathrm{i}=1}^{\mathrm{N}}\left(\mathrm{y}_{\mathrm{prd}, \mathrm{i}}-\mathrm{y}_{\mathrm{m}}\right)}
\end{aligned}
$$

where $\mathrm{y}_{\text {prd.i }}$ was the predicted value by ANN model, $\mathrm{y}_{\text {exp,i }}$ was the experimental value, $\mathrm{N}$ was the number of data and $\mathrm{y}_{\mathrm{m}}$ was the average of the experimental value.

\section{Theory of adsorption isotherm, kinetics and thermody- namics}

Adsorption isotherm models: Adsorption isotherm is basically significant to describe how solutes interact with adsorbents and is critical in optimizing the use of adsorbents ${ }^{2}$. The Langmuir ${ }^{26}$, the Freundlich ${ }^{27}$, the Temkin ${ }^{28}$ and DubininRadushkevich (D-R $)^{29}$ isotherms were applied in this study.

Langmuir isotherm: The Langmuir model can be described by the following equation:

$$
\mathrm{q}_{\mathrm{e}}=\frac{\mathrm{q}_{\mathrm{m}} \mathrm{k}_{\mathrm{L}} \mathrm{C}_{\mathrm{e}}}{1+\mathrm{k}_{\mathrm{L}} \mathrm{C}_{\mathrm{e}}}
$$

The linearized form of the eqn. 5 is

$$
\frac{\mathrm{C}_{\mathrm{e}}}{\mathrm{q}_{\mathrm{e}}}=\frac{\mathrm{C}_{\mathrm{e}}}{\mathrm{q}_{\mathrm{m}}}+\frac{1}{\left(\mathrm{~K}_{\mathrm{L}} \mathrm{q}_{\mathrm{m}}\right)}
$$

where $\mathrm{C}_{\mathrm{e}}(\mathrm{mg} / \mathrm{L})$ and $\mathrm{q}_{\mathrm{e}}(\mathrm{mg} / \mathrm{g})$ are the equilibrium concentration and the amount of dye adsorbed at equilibrium, respectively. $\mathrm{q}_{\mathrm{m}}(\mathrm{mg} / \mathrm{g})$ and $\mathrm{K}_{\mathrm{L}}(\mathrm{L} / \mathrm{mg})$ are Langmuir constants related to adsorption capacity and energy of adsorption, respectively ${ }^{2}$. The constants $\mathrm{q}_{\mathrm{m}}$ and $\mathrm{K}_{\mathrm{L}}$ can be calculated from the plot between $\mathrm{C}_{\mathrm{e}} / \mathrm{q}_{\mathrm{e}}$ versus $\mathrm{C}_{\mathrm{e}}$ (eqn. 6).

Freundlich isotherm: The Freundlich isotherm is an experimental equation is often used to correlate adsorption data. The Freundlich isotherm equation has the following form:

$$
\mathrm{q}_{\mathrm{e}}=\mathrm{K}_{\mathrm{F}} \mathrm{C}_{\mathrm{e}}^{1 / \mathrm{n}}
$$

A linear form of above expression is:

$$
\log \mathrm{q}_{\mathrm{e}}=\log \mathrm{K}_{\mathrm{F}}+\frac{1}{\mathrm{n}} \log \mathrm{C}_{\mathrm{e}}
$$

The Freundlich isotherm constants $\mathrm{K}_{\mathrm{F}}$ and $\mathrm{n}$ can be determined from the plot of versus $\log \mathrm{C}_{\mathrm{e}}$ (eqn. 8). $\mathrm{K}_{\mathrm{F}}\left(\mathrm{mg} \mathrm{L}^{1 / \mathrm{n}} / \mathrm{g}\right.$ $\mathrm{mg}^{1 / \mathrm{n}}$ ) and $\mathrm{n}$ are the Freundlich constants which are indicators of adsorption capacity and adsorption intensity, respectively ${ }^{2}$.

Temkin isotherm: The Temkin equation is given as:

$$
\mathrm{q}_{\mathrm{e}}=\mathrm{B} \ln \mathrm{AC}_{\mathrm{e}}
$$

The Temkin isotherm has generally been applied in the form given as:

$$
\mathrm{q}_{\mathrm{e}}=\mathrm{B} \ln \mathrm{A}+\mathrm{B} \ln \mathrm{C}_{\mathrm{e}}
$$

where $\mathrm{B}=\frac{\mathrm{RT}}{\mathrm{b}}$ the constants $\mathrm{A}$ and $\mathrm{B}$ can be obtained by plotting $\mathrm{q}_{\mathrm{e}}$ versus $\ln \mathrm{C}_{\mathrm{e}}$ (eqn. 10). $\mathrm{B}$ is the Temkin constant related to the heat of sorption $(\mathrm{mg} / \mathrm{g}), \mathrm{A}$ is the Temkin isotherm constant $(\mathrm{L} / \mathrm{mg}), \mathrm{R}$ the gas constant $(8.314 \mathrm{~J} / \mathrm{mol} \mathrm{K})$, b is Temkin isotherm constant $(\mathrm{g} \mathrm{J} / \mathrm{mol} \mathrm{mg}$ ) and $\mathrm{T}$ the absolute temperature $(\mathrm{K})$.

Dubinin-Radushkevich isotherm: The DubininRadushkevich equation can be described via the following equation:

$$
\mathrm{q}_{\mathrm{e}}=\mathrm{q}_{\mathrm{m}} \mathrm{e}^{-\beta \varepsilon^{2}}
$$

A linear form of the eqn. 11 is:

$$
\ln \mathrm{q}_{\mathrm{e}}=\ln \mathrm{q}_{\mathrm{m}}-\beta \varepsilon^{2}
$$

where $\mathrm{q}_{\mathrm{m}}$ is the Dubinin-Radushkevich monolayer capacity $(\mathrm{mg} / \mathrm{g}), \beta$ a constant related to sorption energy $\left(\mathrm{mol}^{2} / \mathrm{K} \mathrm{J}^{2}\right)$ and $\varepsilon$ is the Polanyi potential which is related to the equilibrium concentration as follows:

$$
\varepsilon=\frac{\mathrm{RT}}{\mathrm{M}} \log \left(1+\frac{1}{\mathrm{C}_{\mathrm{e}}}\right)
$$

where, $\mathrm{R}$ is the gas constant $(8.314 \mathrm{~J} / \mathrm{mol} \mathrm{K})$, $\mathrm{T}$ is the absolute temperature and $\mathrm{M}$ is the molecular weight of the adsorbed $^{30-32}$.

Kinetic adsorption isotherm models: The amounts of dye adsorbed at various time periods $\mathrm{q}_{\mathrm{t}}(\mathrm{mg} / \mathrm{g})$ were determined using the mass balance relationship as follows:

$$
\mathrm{q}_{\mathrm{t}}=\left(\mathrm{C}_{0}-\mathrm{C}_{\mathrm{t}}\right) \times\left(\frac{\mathrm{V}}{\mathrm{W}}\right)
$$

where, $\mathrm{C}_{0}$ and $\mathrm{C}_{\mathrm{t}}(\mathrm{mg} / \mathrm{L})$ are the dye concentration at initial and any time (t), respectively, $\mathrm{V}$ is the volume of the solution (L) and $\mathrm{W}$ is the mass of the dry adsorbent used ( $\mathrm{g}$ ).

The well-know models widely used to fit the kinetic sorption experiments are Lagergren's pseudo first order model

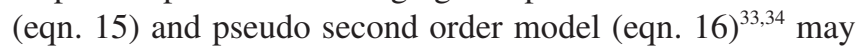
be expressed as:

$$
\begin{aligned}
& \frac{\mathrm{dq}_{\mathrm{t}}}{\mathrm{dt}}=\mathrm{k}_{1}\left(\mathrm{q}_{\mathrm{e}}-\mathrm{q}_{\mathrm{t}}\right) \\
& \frac{\mathrm{dq}_{\mathrm{t}}}{\mathrm{dt}}=\mathrm{k}_{1}\left(\mathrm{q}_{\mathrm{e}}-\mathrm{q}_{\mathrm{t}}\right)^{2}
\end{aligned}
$$


These equations can be re-prepared to give the linear form:

$$
\begin{gathered}
\ln \left(\mathrm{q}_{\mathrm{e}}-\mathrm{q}_{\mathrm{t}}\right)=\ln \mathrm{q}_{\mathrm{e}}-\mathrm{k}_{1} \mathrm{t} \\
\frac{\mathrm{t}}{\mathrm{q}_{\mathrm{t}}}=\frac{1}{\mathrm{k}_{2} \mathrm{q}_{\mathrm{e}}^{2}}+\frac{\mathrm{t}}{\mathrm{q}_{\mathrm{e}}}
\end{gathered}
$$

where $\mathrm{q}_{\mathrm{e}}(\mathrm{mg} / \mathrm{g})$ and $\mathrm{q}_{\mathrm{t}}(\mathrm{mg} / \mathrm{g})$ are amounts of dye absorbed at equilibrium and any time $\mathrm{t}$, respectively. $\mathrm{k}_{1}\left(\mathrm{~min}^{-1}\right)$ and $\mathrm{k}_{2}(\mathrm{~g} /$ $\mathrm{mg} \min )$ are the pseudo-first order and pseudo-second order adsorption rate constants, respectively.

Intraparticle diffusion: Adsorption process includes transporting adsorbate from bulk solution to the surface of the particles of adsorbent followed by diffusion into the interior of the pores. There is a possibility that transporting the solute molecules from the bulk solution into the pores of the solid particulates is rate limiting in batch studies with rapid stirring. Besides, the pseudo first and second order model can not identify the diffusion mechanism. Therefore, the kinetic results were studied by the intraparticle diffusion model to explain the diffusion mechanism, whose model is demonstrated as $^{35}$ :

$$
\mathrm{q}_{\mathrm{t}}=\mathrm{k}_{\mathrm{id}} \mathrm{t}^{1 / 2}+\mathrm{C}_{\mathrm{i}}
$$

where $\mathrm{q}_{\mathrm{t}}(\mathrm{mg} / \mathrm{g})$ is the amount of dye absorbed at any time $\mathrm{t}$, $\left(\mathrm{mg} / \mathrm{g} \mathrm{min}{ }^{1 / 2}\right)$, the rate factor of stage $\mathrm{i}$, which can be evaluated from the slope of the straight line of $\mathrm{q}_{\mathrm{t}}$ versus $\mathrm{t}^{1 / 2}$ and $(\mathrm{mg} / \mathrm{g})$ is the intercept which is proportional to the range of boundary layer thickness ${ }^{36}$.

Thermodynamics studies: Thermodynamic parameters were determined to confirm the adsorption nature of the present investigation. The thermodynamic parameters such as Gibbs free energy change $\left(\Delta \mathrm{G}^{\mathrm{o}}\right)$, enthalpy change $\left(\Delta \mathrm{H}^{\mathrm{o}}\right)$ and entropy change $\left(\Delta S^{\circ}\right)$ were obtained to study the thermodynamic feasibility and the spontaneous nature of the process. The change in enthalpy $\left(\Delta \mathrm{H}^{\circ}\right)$ and entropy $\left(\Delta \mathrm{S}^{\circ}\right)$ are calculated using the following relationship ${ }^{37}$ :

$$
\ln \mathrm{K}_{\mathrm{c}}=\frac{\Delta \mathrm{S}^{\mathrm{o}}}{\mathrm{R}}-\frac{\Delta \mathrm{H}^{\mathrm{o}}}{\mathrm{RT}}
$$

where $\mathrm{K}_{\mathrm{c}}=\mathrm{Fe} /(1-\mathrm{Fe})$ and $\mathrm{Fe}=\left(\mathrm{C}_{0}-\mathrm{C}_{\mathrm{e}}\right) / \mathrm{C}_{\mathrm{e}}$; is the fraction adsorbed at equilibrium, while $\mathrm{T}$ is the temperature in degree $\mathrm{K}$ and $\mathrm{R}$ is the gas constant $[8.314 \mathrm{~J} / \mathrm{mol} \mathrm{K}$ )]. From the slope and the intercept of van't Hoff plots, the values of $\Delta \mathrm{H}^{\circ}$ and $\Delta S^{\circ}$ were calculated.

The Gibbs free energy change $\left(\Delta \mathrm{G}^{\mathrm{o}}\right)$ was obtained using the following expression ${ }^{38}$ :

$$
\Delta \mathrm{G}^{\mathrm{o}}=-\mathrm{RT} \ln \mathrm{K}_{\mathrm{c}}
$$

The amount of activation energy $\left(\mathrm{E}_{\mathrm{a}}\right)$ gives an idea about the type of adsorption which is mainly diffusion-controlled processes or chemical reaction processes. Activation energies below $42 \mathrm{~kJ} / \mathrm{mol}$, generally indicate diffusion-controlled processes and higher values depict chemical reaction processes ${ }^{39}$. This is because of the fact that the temperature dependence of the pore diffusivity is relatively weak. Here, the diffusion process refers to the movement of the solute to an external surface of adsorbent and not diffusivity of material along micropore wall surfaces in a particle. Energy of activation was calculated according to a relationship between $\mathrm{E}_{\mathrm{a}}$ and $\Delta \mathrm{H}^{\circ}$ for reactions in solution using the following equation ${ }^{40}$ :

$$
\mathrm{E}_{\mathrm{a}}=\Delta \mathrm{H}^{\mathrm{o}}+\mathrm{RT}
$$

\section{RESULTS AND DISCUSSION}

Optimization of the artificial neural network structure: Many kinds of networks are developed with different properties and applications. Among these, back propagation (BP) multilayer neural network is the most common and convenient tool. To obtain the optimal model, several topologies of ANN were evaluated and in each step MSE was determined. Fig. 3 shows correlation between MSE and the neuron number at hidden layer. By improving the neuron number from 1-9, the MSE was diminished from 0.0009-0.00016. The MSE minimum value $(0.00011)$ was obtained with 10 hidden neurons. Finally, the MSE is gradually increased with boosting hidden neurons and tends to keep constant. According to the minimum value of the MSE, the network topology which has 10 neurons in hidden layer was selected as the optimal structure. The predicted performances of the optimal models to evaluate adsorption efficiency $(\%)$ relative to experimental values are indicated in Fig. 4. It can be observed that a good agreement between the predictive ability of the model and experimental values was acquired $\left(R^{2}=0.966\right)$.

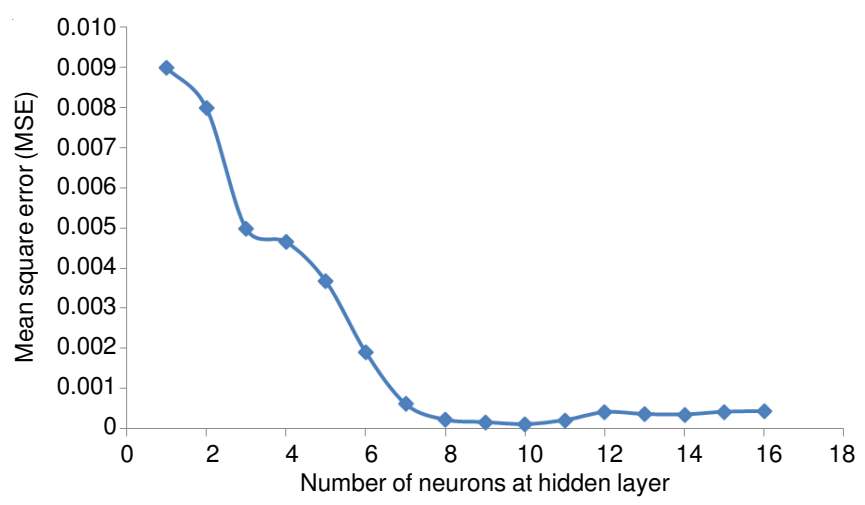

Fig. 3. Correlation between MSE and number of neurons at hidden layer

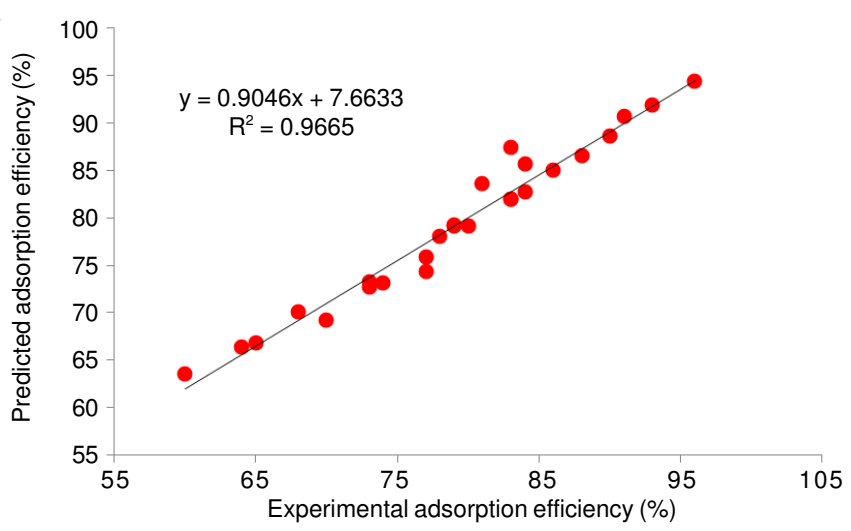

Fig. 4. Correlation of experimental and predicted values of adsorption efficiency $(\%)$ using the optimal network

Impact of particle size: The impact of particle size was investigated using reactive orange 12 dye on rice husk. Fig. 5 displays the results obtained from a batch sorption, experiments which were carried out using diverse reactive orange 12 particle size ranges and the ANN model predictions. As indicated in Fig. 5, the per cent removal of reactive orange 12 on rice husk increased from 78-88 \% with decrease in the particle size from $400-149 \mu \mathrm{m}$. This is due to the enhancement in available surface 


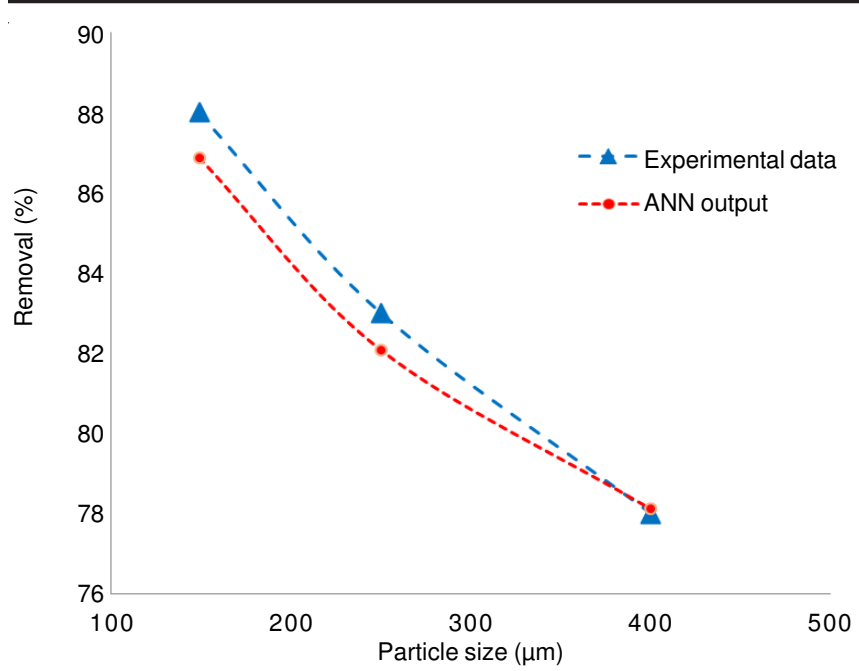

Fig. 5. Impact of particle size on adsorption of reactive orange 12 dye using rice husk $\left(25^{\circ} \mathrm{C}\right.$ temperature, $2 \mathrm{~h}$ contact time, $3.0 \mathrm{~g}$ adsorbent dose, $\mathrm{pH} 3$ and $20 \mathrm{mg} / \mathrm{L}$ initial dye concentration)

area with the decline in particle size ${ }^{41}$. Ozacar and Sengil ${ }^{3}$ reported, in addition to adsorption at the outside surface of the adsorbent, may which intraparticle diffusion from the outside surface into the pores of the material is another reason for increase the per cent removal with decline in particle size. In other words, large particles have a great diffusional resistance to mass transfer. As the results show, it can be found that there is a good agreement between the predictive ability of the model and obtained experimental values.

Impact of initial dye concentration: Initial concentration is one of the significant parameters on adsorption efficiency. The experiments were carried out with different initial reactive orange 12 dye concentration ranging from 10-70 mg/L. The results of experiments predicted by optimal the ANN model for the influence of initial reactive orange 12 dye concentration on removal efficiency were presented in Fig. 6. As the results show, reactive orange 12 dye removal efficiency decreased from $91-68 \%$ with an increase in initial reactive orange 12 dye concentration from $10-70 \mathrm{mg} / \mathrm{L}$. When the reactive orange 12 dye concentrations is low, the ration of the initial number of moles of reactive orange 12 dye molecule to the available surface area of adsorbent will be large and subsequently the fractional adsorption becomes independent of initial concentration. However, at higher concentrations, the available sites of adsorption become fewer. Therefore, the percentage removal of reactive orange 12 dye molecule will decrease when the initial concentration increases ${ }^{2}$. It can be observed that the experimental data have a good agreement with data obtained by the ANN model.

Impact of pH: The effect of $\mathrm{pH}$ on the adsorption of the reactive orange 12 dye by rice husk was investigated at ambient temperature $\left(25^{\circ} \mathrm{C}\right) . \mathrm{pH}$ is one of the most significant parameters controlling the adsorption of dye by adsorbent particles, which changes both the surface charge of the adsorbents and the degree of ionization of different adsorbates. $\mathrm{pH}$ changes, alters the adsorption or repulsion process through dissociation of functional groups on the adsorbent surface active sites.

Fig. 1 shows that the reactive orange 12 dye has three sulfo functional groups which under strong acidic conditions

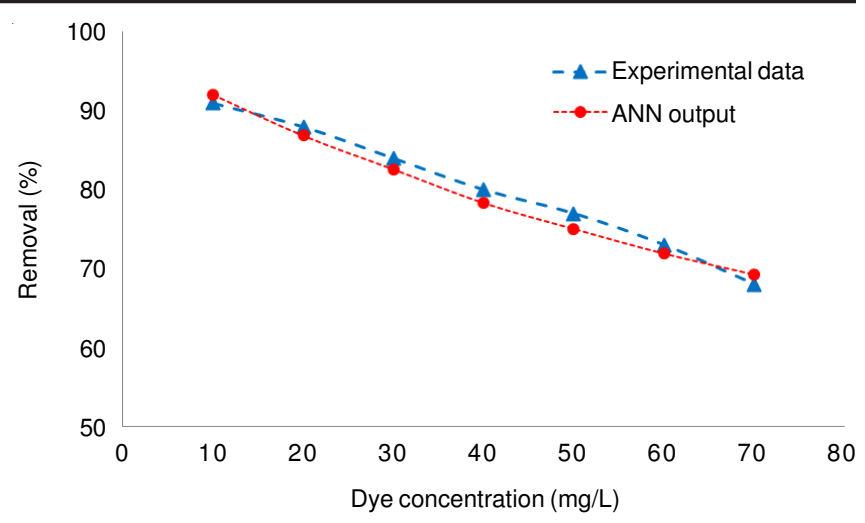

Fig. 6. Impact of initial dye concentration on adsorption of reactive orange 12 using rice husk $\left(25^{\circ} \mathrm{C}\right.$ temperature, $2 \mathrm{~h}$ contact time, $3.0 \mathrm{~g}$ adsorbent dose, $\mathrm{pH} 3$ and $150 \mu \mathrm{m}$ particle size)

exists as molecular form. However, dissociated form of this dye predominates under high $\mathrm{pH}$. At high $\mathrm{pH}$ sulfo groups in this dye can dissociate to form $\mathrm{Na}^{+}$and its corresponding anion.

Rice husk in its natural state involves a high proportion of cellulose $(32.34 \%)$ and this cellulosic surface will alter partially negatively charged when soaked in water ${ }^{12}$. Therefore, this negatively charged can create interaction with cationic species and attracts them but repulses anionic species.

The per cent removal of the reactive orange 12 dye was found to decrease with the increase in the $\mathrm{pH}$ of the solution (Fig. 7), which can be elucidated by the electrostatic expulsive force of anionic reactive orange 12 dye with the negatively charged hydrolyzed rice husk surface. This expulsive force between the reactive orange 12 dye and rice husk is increased with improving of $\mathrm{pH}^{42}$. Fig. 7 also indicates that results obtained the ANN model are in good agreement with the experimental data.

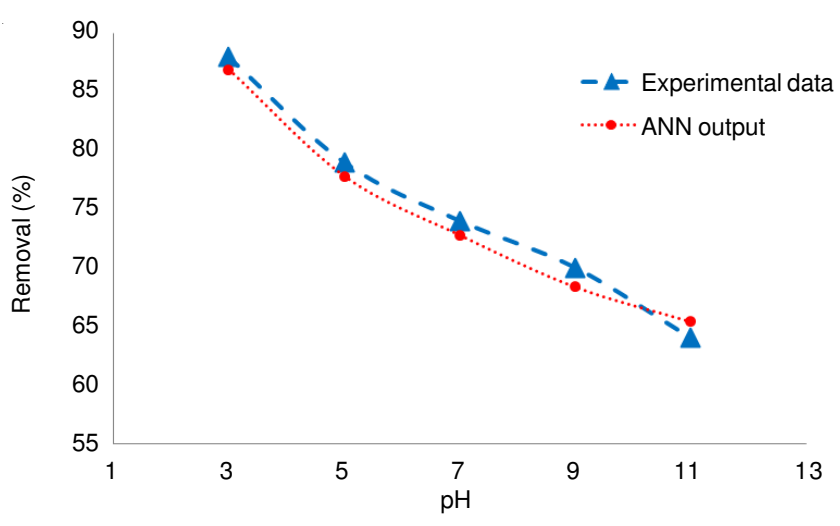

Fig. 7. Impact of $\mathrm{pH}$ on adsorption of reactive orange 12 using rice husk $\left(25^{\circ} \mathrm{C}\right.$ temperature, $2 \mathrm{~h}$ contact time, $3.0 \mathrm{~g}$ adsorbent dose, $20 \mathrm{mg}$ / $\mathrm{L}$ dye concentration and $150 \mu \mathrm{m}$ particle size)

Impact of contact time: Fig. 8 indicates the impact of contact time on adsorption efficiency $(\%)$ of reactive orange 12 by rice husk. The obtained results of experiments and the ANN model displayed that adsorption rate primarily improved and then to be constant with time. In other words, the amount of dye adsorbed amplified with increase in contact time and reached equilibrium after $2 \mathrm{~h}$. For example, the per cent removal was improved from 73-88 \% when contact time was increased from $0.5-2.0 \mathrm{~h}$ and there was no significant change in equilibrium 


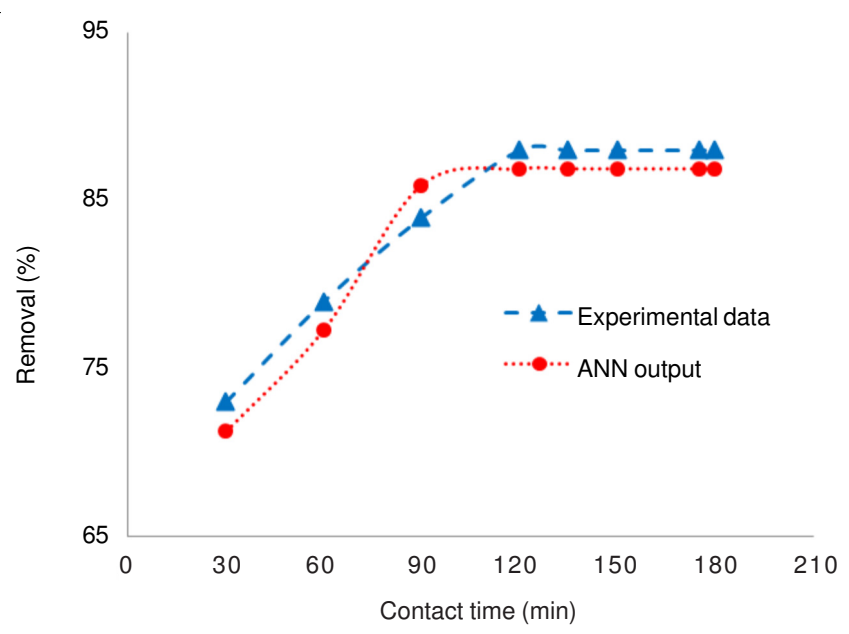

Fig. 8. Impact of contact time on adsorption of reactive orange 12 dye

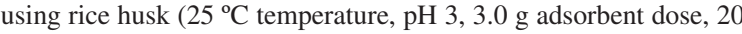
$\mathrm{mg} / \mathrm{L}$ dye concentration and $150 \mu \mathrm{m}$ particle size)

concentration after $120 \mathrm{~min}$ up to $180 \mathrm{~min}$. Therefore, the equilibrium was obtained after $2 \mathrm{~h}$ for this dye. Similar results have been obtained for the removal of dyes ${ }^{43}$. Kannan and Sundaram ${ }^{43}$ reported, in batch type adsorption systems, monolayer of adsorbate is usually formed on the surface of adsorbent and the rate of removal of adsorbate species from aqueous solution is controlled initially by the rate of transportation of the adsorbate species form the outer sites to the internal sites of the adsorbent particles. El-Latif et $a .^{2}$ displayed that the attractive forces between the dye molecule and the adsorbent such as van der Waals forces and electrostatic attractions is a reason for the effect of contact time on adsorption efficiency $(\%)$ on the absorbent ${ }^{2}$. Therefore, fast diffusion onto the external surface was followed by fast pore diffusion into the intraparticle matrix to reach equilibrium at $2 \mathrm{~h}$. Fig. 8 showed that there is a good agreement between the experimental data and predictions of the ANN model.

Impact of temperature: Fig. 9 shows the results of the experiments and predicted by optimal the ANN model for effect of temperature on removal efficiency $(\%)$ of reactive orange 12 using rice husk. The dependence of the removal of reactive orange 12 on temperature has been studied in the range of 25$65{ }^{\circ} \mathrm{C}$. El-Latif et al. ${ }^{2}$ reported that the temperature has two major impacts on the adsorption process. The adsorption capacity enhances with temperature due to the increase of the diffusion rate of the adsorbate molecules across the external boundary layer and the internal pores of the adsorbent particle whose decreases in case of viscosity of the solution for highly concentrated suspensions. In addition, changing the temperature will alter the equilibrium capacity of the adsorbent for a particular adsorbate ${ }^{2}$. It is clear that with the raise of temperature from 25 to $65{ }^{\circ} \mathrm{C}$ the amount of reactive orange 12 removal efficiency (\%) increases from 83 to $96 \%$. This is readily illustrated by the amount of $\Delta \mathrm{H}^{\circ}$ that was calculated using thermodynamic studies. The positive amount of $\Delta \mathrm{H}^{\mathrm{o}}$ $(32.94 \mathrm{~J} / \mathrm{mol}$ ) displays that the adsorption reaction is endothermic, therefore, increasing the temperature led to a higher adsorption of reactive orange 12 dye using rice husk. As the results show, it can be observed that the optimal ANN model output and experimental data have a good agreement.

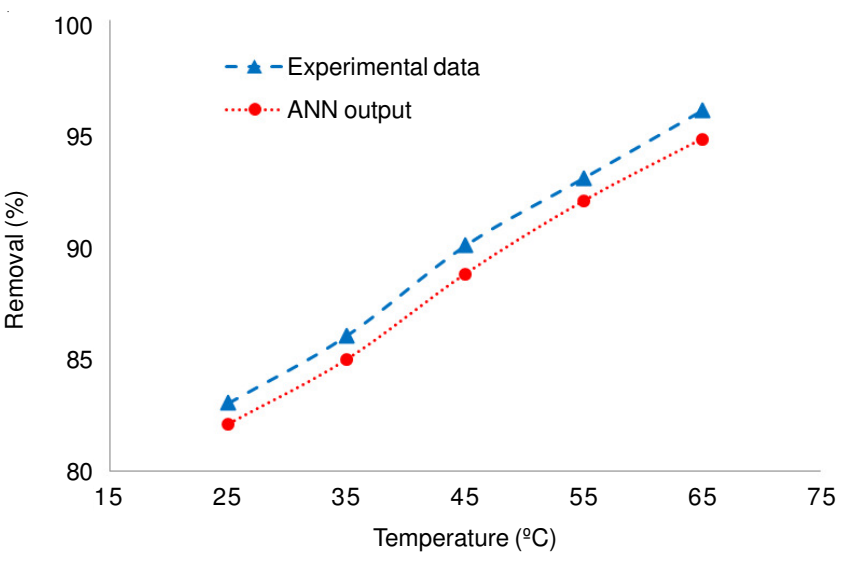

Fig. 9. Impact of temperature on adsorption of reactive orange 12 using rice husk ( $\mathrm{pH} \mathrm{3,2}$ h contact time, $3.0 \mathrm{~g}$ adsorbent dose, $20 \mathrm{mg} / \mathrm{L}$ dye concentration and $250 \mu \mathrm{m}$ particle size)

Impact of adsorbent dose: The effect of adsorbent amount on the removal efficiency (\%) of reactive orange 12 is shown in Fig. 10. The experiments were performed by mixing $50 \mathrm{~mL}$ aqueous solution of dye $(20 \mathrm{mg} / \mathrm{L})$. Results show that the reactive orange 12 dye removal efficiency ( $\%$ ) presented a significant improvement with the increase in adsorbent amount. The per cent removal of reactive orange 12 dye by rice husk varied from 60-88 \% with an increase in adsorbent amount from 0.5 $3.0 \mathrm{~g}$. This can be illustrated that the enhancement of the adsorbent mass increases the effective surface area or in other words, boosts the number of active uptake $\operatorname{sites}^{3,22}$. From Fig. 10 , it can be seen that obtained the results from optimal ANN model are in good agreement with experimental data.

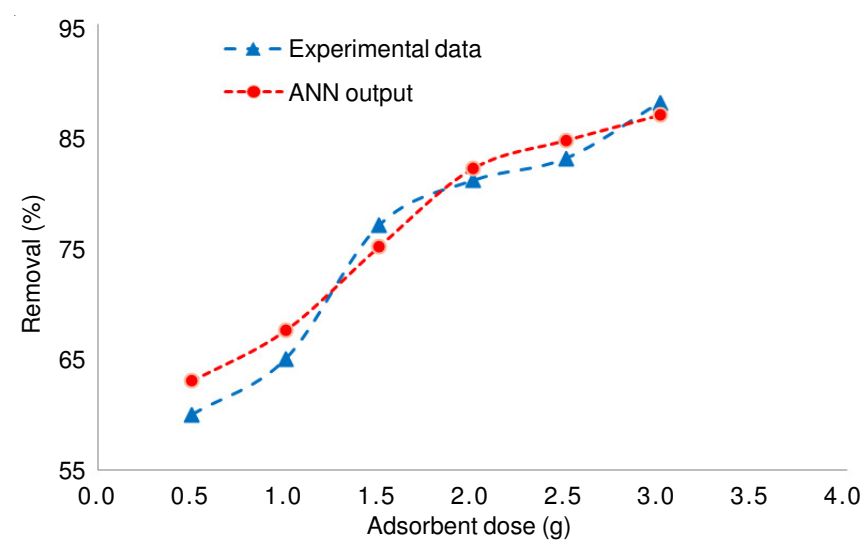

Fig. 10. Impact of adsorbent dose on adsorption of reactive orange 12 dye using rice husk $\left(25^{\circ} \mathrm{C}\right.$ temperature, $\mathrm{pH} 3,2 \mathrm{~h}$ contact time, $20 \mathrm{mg}$ / $\mathrm{L}$ dye concentration and $250 \mu \mathrm{m}$ particle size)

Adsorption isotherms: In this study, the distribution of reactive orange 12 between the liquid phase and the adsorbent (rice husk) were modeled by several isotherm models such as Langmuir, Freundlich, Temkin and Dubinin-Radushkevich (D-R). Fig. 11 indicates the linear plot of specific adsorption $\left(\mathrm{C}_{\mathrm{e}} / \mathrm{q}_{\mathrm{e}}\right)$ versus the equilibrium concentration $\left(\mathrm{C}_{\mathrm{e}}\right)$. The Langmuir constants $\mathrm{q}_{\mathrm{m}}$ and $\mathrm{K}_{\mathrm{L}}$ were obtained from the slope and intercept (Fig. 11) and are exhibited in Table-1. The value of the determination coefficient $\left(\mathrm{R}^{2}=0.993\right)$ determined from Langmuir model shows that this model has a good linearity. The basic features of the Langmuir of the isotherm can be indicated 


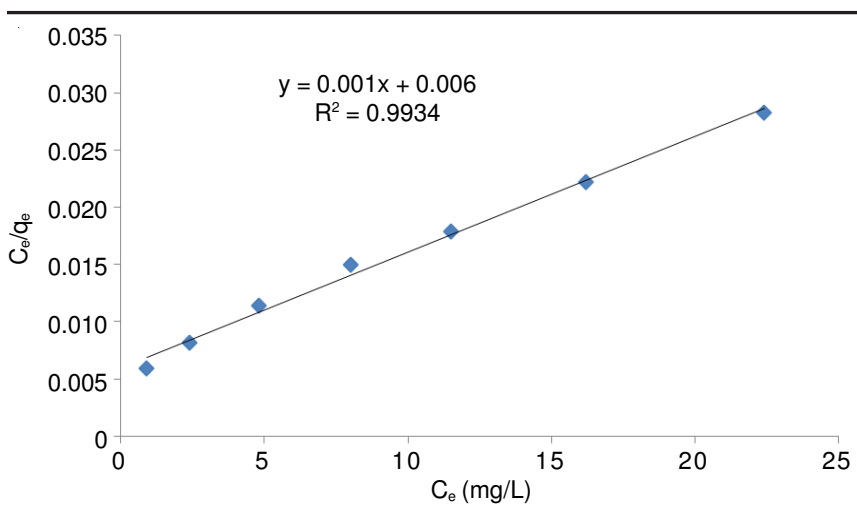

Fig. 11. Langmuir isotherm curve for adsorption of reactive orange 12 using rice husk

in terms of a dimensionless constant separation factor $\mathrm{R}_{\mathrm{L}}$ that is defined by the following equation ${ }^{44}$ :

\begin{tabular}{ccc}
\multicolumn{3}{c}{ TABLE-1 } \\
ISOTHERM PARAMETERS FOR REMOVAL OF \\
RO 12 DYE USING RICE HUSK \\
\hline Isotherms & Parameters & Value \\
\hline \multirow{3}{*}{ Langmuir } & $\mathrm{q}_{\mathrm{m}}\left(\mathrm{mg} / \mathrm{g}^{\prime}\right.$ & 1000 \\
& $\mathrm{~K}_{\mathrm{L}}(\mathrm{L} / \mathrm{mg})$ & 0.1667 \\
& $\mathrm{R}^{2}$ & 0.993 \\
\hline \multirow{3}{*}{ Freundlich } & $\mathrm{K}_{\mathrm{F}}\left(\mathrm{mg} / \mathrm{g}(\mathrm{L} / \mathrm{g})^{1 / \mathrm{n}}\right)$ & 175.39 \\
& $\mathrm{n}$ & 1.938 \\
& $\mathrm{R}^{2}$ & 0.986 \\
\hline \multirow{2}{*}{ Temkin } & $\mathrm{A}(\mathrm{L} / \mathrm{g})$ & 1.931 \\
& $\mathrm{~B}\left(\mathrm{~J} / \mathrm{mol}^{2}\right)$ & 205.2 \\
& $\mathrm{R}^{2}$ & 0.984 \\
\hline Dubinin- & $\mathrm{q}_{\mathrm{m}}(\mathrm{mg} / \mathrm{g})$ & 592.885 \\
Radushkevich & $\beta\left(\mathrm{mol}{ }^{2} / \mathrm{KJ}\right)$ & 0.426 \\
(D-R) & $\mathrm{R}^{2}$ & 0.821 \\
\hline
\end{tabular}

$$
\mathrm{R}_{\mathrm{L}}=\frac{1}{\left(1+\mathrm{K}_{\mathrm{L}} \mathrm{C}_{0}\right)}
$$

where, $\mathrm{C}_{0}$ is the initial reactive orange 12 concentration $(\mathrm{mg} / \mathrm{L})$ and $\mathrm{K}_{\mathrm{L}}(\mathrm{L} / \mathrm{mg})$ is Langmuir constant. The $\mathrm{R}_{\mathrm{L}}$ value displays the state of the isotherm which is favorable $\left(0<R_{L}<1\right)$, linear $\left(R_{L}=1\right)$, irreversible $\left(R_{L}=0\right)$ and unfavorable $\left(R_{L}>1\right)^{31}$. The values of $R_{L}$ for the adsorption of reactive orange 12 on rice husk (Table-2) are found to be in the range $0-1$. It is proved that adsorption of reactive orange 12 on rice husk is a favourable process. The Freundlich parameters $\left(\mathrm{K}_{\mathrm{F}}, \mathrm{n}\right)$ and determination coefficient $\left(\mathrm{R}^{2}\right)$ were calculated by plotting $\log \mathrm{q}_{\mathrm{e}}$ against $\log$ $\mathrm{C}_{\mathrm{e}}$ (Fig. 12, Table-1). The determination coefficient $\left(\mathrm{R}^{2}=\right.$ 0.986) exhibits a good fit to the experimental adsorption equilibrium data. The results indicate that the value of $n$ equal to 1.938 which demonstrates the dye is suitably adsorbed on adsorbent ${ }^{45}$. Fig. 13 displays Temkin isotherm curve for adsorption of reactive orange 12 on rice husk $\left(\mathrm{q}_{\mathrm{e}}\right.$ versus $\left.\ln \mathrm{C}_{\mathrm{e}}\right)$. The obtained Temkin isotherm constants (A, B) as well as the determination coefficientare indicated in Table-1. The coefficient of correlation $\left(\mathrm{R}^{2}=0.984\right)$ indicates that Temkin isotherm displays a less fit to adsorption data than the Langmuir and the Freundlich isotherms. The adsorption of reactive orange 12 on rice husk was analyzed by a regression analysis to fit the Dubinin-Radushkevich (D-R) isotherm model (Fig. 14). The parameters and the determination coefficient for this modal
TABLE-2

VALUES OF $\mathrm{R}_{\mathrm{L}}$ FOR VARIOUS CONCENTRATIONS

\begin{tabular}{cc}
\hline Dye concentration $(\mathrm{mg} / \mathrm{L})$ & Value of $\mathrm{R}_{\mathrm{L}}$ \\
\hline 10 & 0.375 \\
20 & 0.231 \\
30 & 0.167 \\
40 & 0.130 \\
50 & 0.107 \\
60 & 0.091 \\
70 & 0.079 \\
\hline
\end{tabular}

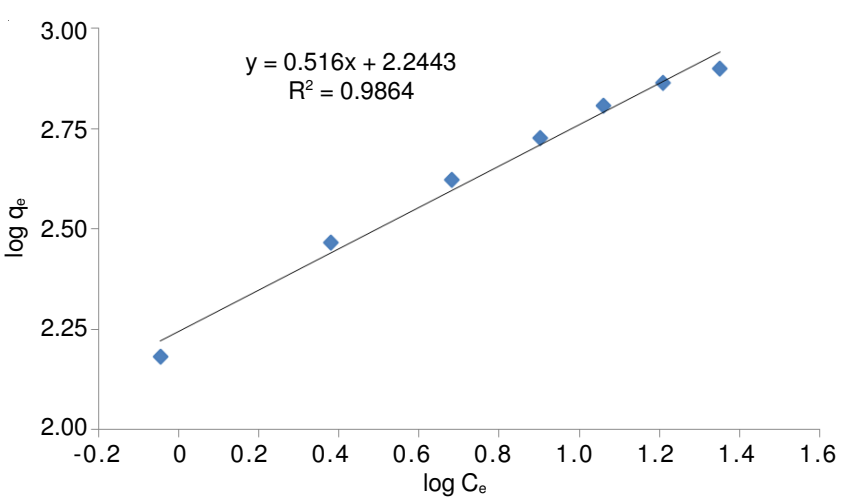

Fig. 12. Freundlich isotherm curve for adsorption of reactive orange 12 using rice husk

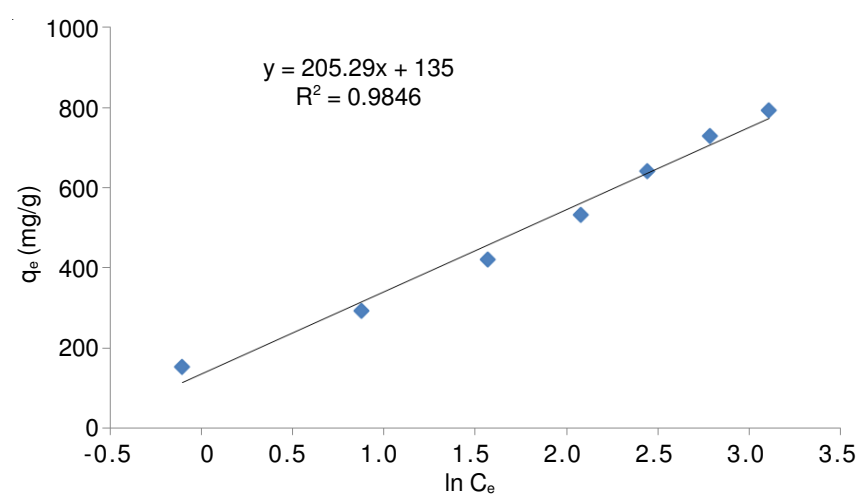

Fig. 13. Temkin isotherm curve for adsorption of reactive orange 12 using rice husk

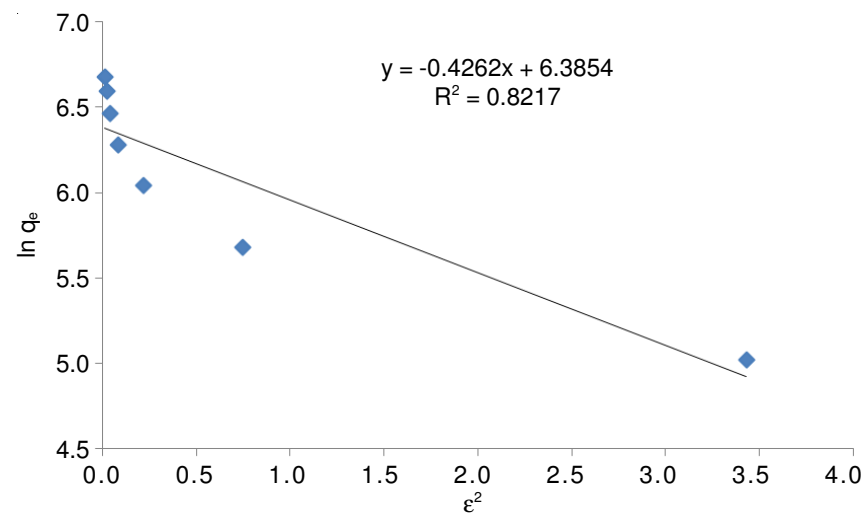

Fig. 14. Dubinin-Radushkevich (D-R) isotherm curve for adsorption of reactive orange 12 using rice husk

are represented in Table-1. The determination coefficient $\left(\mathrm{R}^{2}\right.$ $=0.821)$ indicates that the Dubinin-Radushkevich (D-R) isotherm shows the poor fit to experimental data than the other isotherm models. The results indicated that Langmuir isotherm model was the best model for the adsorption of reactive orange 12 on rice husk because of the high value of determination 
coefficient $\left(R^{2}=0.993\right)$. The reason for this result may be due to homogenous distribution of active sites on the absorbent ${ }^{3}$.

Kinetics of adsorption: In order to provide information about the controlling mechanism of adsorption process the applicability of the pseudo-first order and pseudo-second order was studied for adsorption of reactive orange 12 on rice husk. The best mechanism was chosen based on the linear regression determination coefficient $\left(\mathrm{R}^{2}\right)$ values. The kinetics of adsorption of reactive orange 12 on rice husk at $25^{\circ} \mathrm{C}$ and different initial concentrations (20 and $40 \mathrm{mg} / \mathrm{L}$ ) were studied. The kinetics parameters for the adsorption process were investigated for contact times ranging from 15 to $150 \mathrm{~min}$. using eqn. $17, \ln \left(\mathrm{q}_{\mathrm{e}}-\mathrm{q}_{\mathrm{t}}\right)$ against $\mathrm{t}$ and eqn. $18, \mathrm{t} / \mathrm{q}_{\mathrm{e}}$ versus $\mathrm{t}$, were plotted at different concentration of dye and are shown in Figs. 15 and 16, respectively. The slope and intercepts of these curves were used to obtain the values of $\mathrm{K}_{1}$ and $\mathrm{K}_{2}$, as well as the equilibrium capacity $\left(\mathrm{q}_{\mathrm{e}, \mathrm{cal}}\right)$. Table-3 indicates kinetic constants, $\mathrm{q}_{\mathrm{e}, \mathrm{cal}}$ and determination coefficient for the first and the second order models. The results display that the adsorption of reactive orange 12 on rice husk may be best elucidated by the pseudosecond order kinetic model with higher correlation coefficients $\left(R^{2}=0.999\right)$ than the pseudo-first order $\left(R^{2}=0.965\right)$. It can be observed that $\mathrm{K}_{2}$ decreases with enhancing initial dye concentration. Increasing initial dye concentration causes the dye molecules to join together and create dense masses which lead to decline dye diffusivity; consequently, the absorption rate of dye decreases ${ }^{2}$.

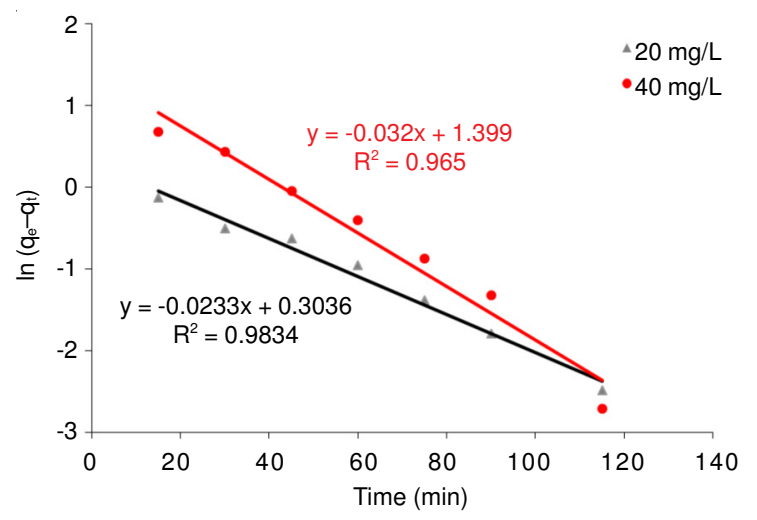

Fig. 15. First-order plots of reactive orange 12 using rice husk $\left(25^{\circ} \mathrm{C}\right.$ temperature, $\mathrm{pH} \mathrm{3,2} \mathrm{h}$ contact time, $3.0 \mathrm{~g}$ adsorbent dose and 250 $\mu \mathrm{m}$ particle size)

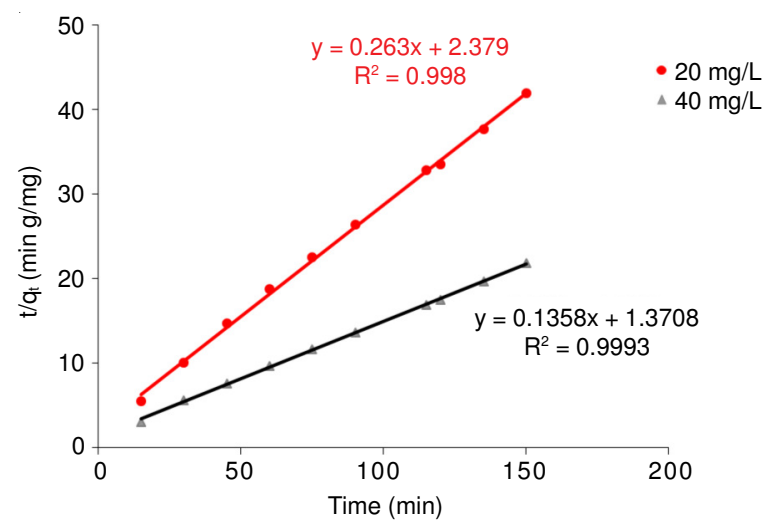

Fig. 16. Second-order plots of reactive orange 12 using rice husk $\left(25^{\circ} \mathrm{C}\right.$ temperature, $\mathrm{pH} \mathrm{3,2}$ h contact time, $3.0 \mathrm{~g}$ adsorbent dose and 250 $\mu \mathrm{m}$ particle size)

\begin{tabular}{lcc}
\multicolumn{3}{c}{ TABLE-3 } \\
& KINETIC PARAMETERS FOR REMOVAL OF \\
& REACTIVE ORANGE 12 USING RICE HUSK \\
\hline \multicolumn{3}{c}{ Dye concentration $(\mathrm{mg} / \mathrm{L})$} \\
\hline \multicolumn{3}{c}{ First-order } \\
\hline \multicolumn{3}{c}{40} \\
\hline $\mathrm{k}_{1}\left(\mathrm{~min}^{-1}\right)$ & 0.0233 & 0.0327 \\
$\mathrm{q}_{\mathrm{e}}(\mathrm{mg} / \mathrm{g})$ & 1.354727 & 4.053173 \\
$\mathrm{R}^{2}$ & 0.9834 & 0.9652 \\
\hline & Second-order \\
\hline $\mathrm{k}_{2}\left(\mathrm{~g} / \mathrm{mg} \mathrm{min}^{2}\right.$ & 0.029184 \\
$\mathrm{q}_{\mathrm{e}}(\mathrm{mg} / \mathrm{g})$ & 3.795066 & 0.013453 \\
$\mathrm{R}^{2}$ & 0.9986 & 7.36377 \\
$\mathrm{t}_{0.5}(\mathrm{~min})$ & 9.028843 & 0.9993 \\
$\mathrm{D}^{2} \times 10^{-8}\left(\mathrm{~cm}^{2} / \mathrm{s}\right)$ & 1.22945 & 10.09426 \\
\hline & Intraparticle diffusion \\
\hline $\mathrm{k}_{1 \mathrm{~d}}\left(\mathrm{mg} / \mathrm{g} \mathrm{min}{ }^{1 / 2}\right)$ & 0.125 & 1.09968 \\
$\mathrm{C}_{1}(\mathrm{mg} / \mathrm{g})$ & 2.236 & 0.335 \\
$\mathrm{R}_{1}{ }^{2}$ & 0.78 & 3.581 \\
$\mathrm{k}_{2 \mathrm{~d}}\left(\mathrm{mg} / \mathrm{g} \mathrm{min}{ }^{1 / 2}\right)$ & 0.062 & 0.989 \\
$\mathrm{C}_{2}(\mathrm{mg} / \mathrm{g})$ & 2.824 & 0.102 \\
$\mathrm{R}_{2}{ }^{2}$ & 0.845 & 5.639 \\
\hline & & 0.817 \\
\hline
\end{tabular}

Adsorption mechanism: Generally, the adsorption process is a multisteps process that is mainly includes the following steps. (i) movement of the adsorbate from bulk of solution, (ii) film diffusion (mass transfer of adsorbate through the boundary layer), (iii) adsorption of adsorbate onto active sites on the surface of adsorbent and (iv) intraparticle diffusion. The slowest step controls the overall rate of the adsorption process $^{46}$.

The possibility of intraparticle diffusion was investigated by using the eqn. 19 . The plot would pass through the origin if the intraparticle diffusion were the sole rate limiting step, otherwise, the boundary layer diffusion was rate limiting. Besides, intercept values give information about the boundary layer thickness; therefore, the higher intercept value the greater is the boundary layer effect ${ }^{47}$. If the values of the slope vary from 0.5 , it will display that the contribution of intraparticle diffusion is one of the rate controlling steps ${ }^{10}$. Fig. 17 shows the adsorption data for intraparticle diffusion model ( $\mathrm{q}_{\mathrm{t}}$ versus $\mathrm{t}^{1 / 2}$ ) for the reactive orange $12 \mathrm{using}$ rice husk. From this figure it was seen that there are two linear portions. It may seem that the first linear portion displays the boundary layer diffusion effect (mass transfer) and the second linear portion is the result of intraparticle diffusion effects ${ }^{48,49}$. The values of $K_{i d}, C_{i}$ and $\mathrm{R}^{2}$ at different initial concentrations are calculated from the two straight lines (Fig. 17) and these results are given in Table-3. As shown in Fig. 17, the straight lines vary from origin. Thus the deviations from the origin display that the pore or intraparticle diffusion is not the only rate limiting step ${ }^{50}$.

Moreover, the adsorption rate limiting step can be correlated to the pore and film diffusion coefficients ${ }^{51}$. For instance, for film diffusion to be rate controlling, the value of film diffusion (D) should be between $10^{-6}$ and $10^{-8} \mathrm{~cm}^{2} / \mathrm{s}$ and for pore diffusion to be controlling, the pore diffusion coefficient should be in the range of $10^{-11}-10^{-13} \mathrm{~cm}^{2} / \mathrm{s}$.

The half adsorption time $\left(\mathrm{t}_{0.5}\right)$ is described as the time required for the adsorption to take up half as much absorbent as its equilibrium value. The $t_{0.5}$ is often used as an amount of the adsorption rate which is obtained using the following relationship: 


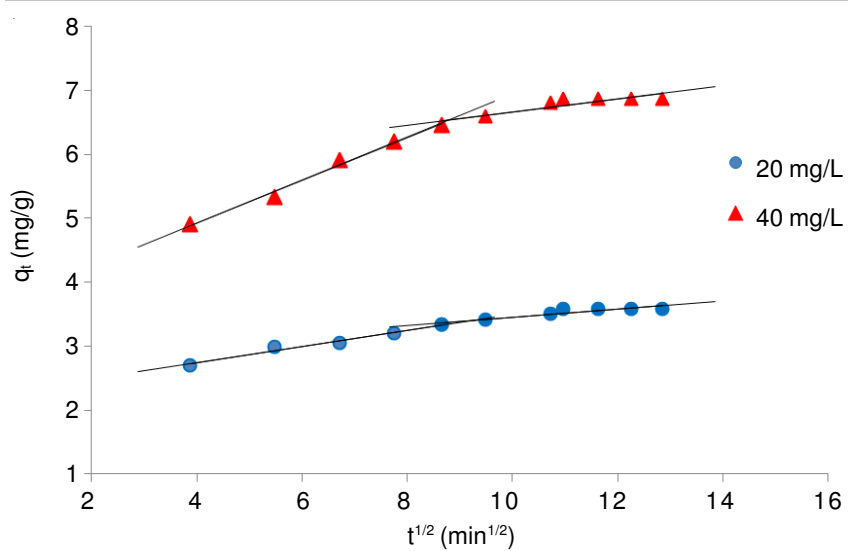

Fig. 17. Intraparticle diffusion plots of reactive orange 12 using rice husk $\left(25^{\circ} \mathrm{C}\right.$ temperature, $\mathrm{pH} \mathrm{3,2} \mathrm{h}$ contact time, $3.0 \mathrm{~g}$ adsorbent dose and $250 \mu \mathrm{m}$ particle size)

$$
\mathrm{t}_{0.5}=\frac{1}{\mathrm{~K}_{2} \mathrm{q}_{\mathrm{e}}}
$$

The coefficient of pore diffusion mainly depends on the surface properties of adsorbents and was obtained using the following equation ${ }^{9,51}$ :

$$
\mathrm{t}_{0.5}=\frac{0.3 \mathrm{r}_{0}^{2}}{\mathrm{D}}
$$

where $t_{0.5}(\mathrm{~min})$ as obtained from eqn. $24, \mathrm{r}_{0}$ is the radius of the adsorbents particle $(\mathrm{cm})$ and $\mathrm{D}$ is the diffusion coefficient $\left(\mathrm{cm}^{2} / \mathrm{s}\right)$.

In this study, it has been supposed that the solid phase consists of spherical particles with an average radius about $1.49 \times 10^{-2} \mathrm{~cm}$ for rice husk samples. Obtained amounts of and $\mathrm{D}$ are shown in Table-3. As results show, the pore diffusion coefficient was obtained to be in the order of $10^{-8} \mathrm{~cm}^{2} / \mathrm{s}$ that reveals that the pore diffusion is not the sole rate controlling. In other words, the value of pore diffusion coefficient confirms the idea that boundary layer diffusion is the rate limiting step because the overall rate of adsorption process is limited bye the slowest step.

Thermodynamics studies: Fig. 18 displays the influence of temperature on dye kinetic adsorption on rice husk. The thermodynamic parameters for this adsorption were obtained and represented in Table-4.

TABLE-4

THERMODYNAMIC PARAMETERS AND ACTIVATION ENERGY FOR REMOVAL OF REACTIVE ORANGE 12 USING RICE HUSK

\begin{tabular}{ccccc}
\hline $\begin{array}{c}\text { Temperature } \\
(\mathrm{K})\end{array}$ & $\begin{array}{c}\Delta \mathrm{G}^{\circ} \\
(\mathrm{KJ} / \mathrm{mol})\end{array}$ & $\begin{array}{c}\mathrm{E}_{\mathrm{a}} \\
(\mathrm{KJ} / \mathrm{mol})\end{array}$ & $\begin{array}{c}\Delta \mathrm{H}^{\circ} \\
(\mathrm{J} / \mathrm{mol})\end{array}$ & $\begin{array}{c}\Delta \mathrm{S}^{\circ} \\
(\mathrm{J} / \mathrm{mol})\end{array}$ \\
\hline 298.15 & -3.930 & 8.165 & & \\
308.15 & -4.651 & 8.439 & & \\
318.15 & -5.812 & 8.713 & 32.94 & 122.63 \\
328.15 & -7.057 & 8.987 & & \\
338.15 & 8.934 & 9.261 & & \\
\hline
\end{tabular}

The amounts of $\Delta \mathrm{H}^{\circ}$ and $\Delta \mathrm{S}^{\circ}$ have been calculated from slope and the intercept of the Fig. 18 that shows an acceptable coefficient of determination $\left(\mathrm{R}^{2}=0.98\right)$. Furthermore, the Gibbs free energy change $\Delta \mathrm{G}^{\mathrm{o}}$ was obtained using eqn. 21 . The positive amount of $\Delta \mathrm{H}^{\circ}(32.94 \mathrm{~J} / \mathrm{mol})$ displays that the adsorption reaction is endothermic, so increasing the temperature led to a

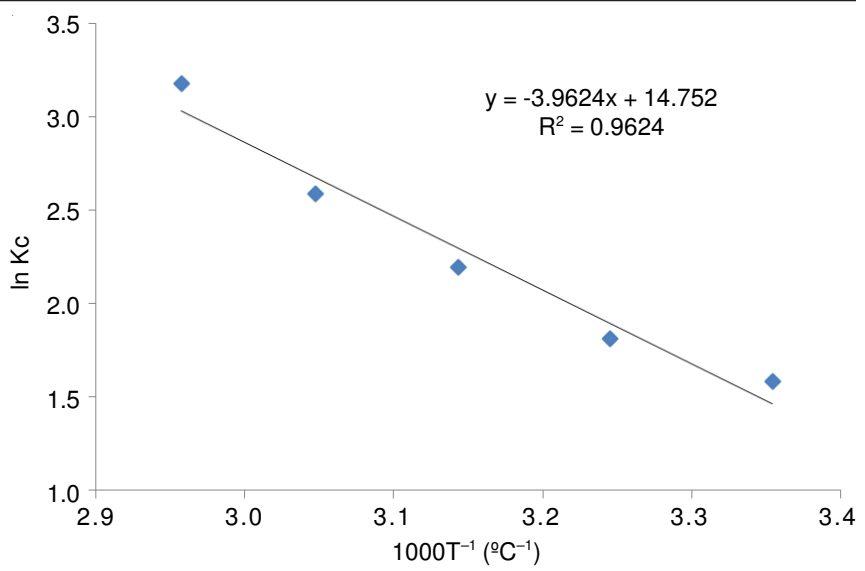

Fig. 18. Impact of temperature on kinetic adsorption of reactive orange 12 using rice husk ( $\mathrm{pH} \mathrm{3,2}$ h contact time, $3.0 \mathrm{~g}$ adsorbent dose, 20 $\mathrm{mg} / \mathrm{L}$ dye concentration and $250 \mu \mathrm{m}$ particle size)

higher adsorption of reactive orange 12 at equilibrium, while the value of $\Delta S^{o}(104.67 \mathrm{KJ} / \mathrm{mol})$ is positive, indicates that the boosting randomness at the solid/liquid interface during the adsorption of reactive orange 12 on rice husk. The negative $\Delta \mathrm{G}^{\mathrm{o}}$ values exhibit that the adsorption process is a spontaneous process. The decline in the negative amount of $\Delta \mathrm{G}^{\mathrm{o}}$ with an intensifier in temperature reveals that the adsorption of reactive orange 12 on rice husk becomes more favorable at higher temperature $^{49}$.

In this study, the activation energy was studied and the results are displayed in Table- 4 . The value of the activation energy presented an idea about the type of adsorption, which was principally physical or chemical. Low activation energies $(5-40 \mathrm{~kJ} / \mathrm{mol})$ are features for physical adsorption, whereas higher activation energies (40-800 kJ/mol) advocate chemisorption $^{11}$. The results calculated (29.91-30.24 kJ/mol) were lower than $40 \mathrm{KJ} / \mathrm{mol}$. Therefore, adsorption of reactive orange 12 on rice husk occurs by physical adsorption spontaneous and endothermic adsorption.

\section{Conclution}

Rice husk applied as a low cost adsorption indicated significant adsorption capacity for removal of reactive orange 12 under suitable experimental conditions. The impact of diverse operational parameters was studied and optimized. Batch adsorption experiments indicated that the optimum operating conditions for adsorption reactive orange 12 using rice husk were $3.0 \mathrm{~g}$ adsorbent dose, $150 \mu \mathrm{m}$ particle size, $10 \mathrm{mg} / \mathrm{L}$ initial concentration of dye, $2 \mathrm{~h}$ contact time, $35^{\circ} \mathrm{C}$ temperature and $\mathrm{pH}$ 3. The results show that the adsorption efficiency (\%) is increased with elevating contact time, temperature and adsorbent dose but is decreased with increasing $\mathrm{pH}$, dye concentration and particle size. A three layer BP-ANN with a tangent sigmoid transfer at hidden layer and a linear transfer function at output layer with 10 neuron numbers at hidden layer is successfully used to model the adsorption of reactive orange 12 using rice husk. The data predictions by optimal ANN model were in good agreement with the experimental data. Equilibrium data indicated that Langmuire isotherm was found to be the optimum isotherm. The kinetics of adsorption of reactive orange 12 using rice husk can be described by pseudo second order better than pseudo first equation. The thermodynamic parameters were 
obtained and the positive enthalpy illustrates the endothermic process. Intraparticle diffusion study indicates that the overall rate of adsorption limited by both boundary layer diffusion at the beginning of adsorption and intraparticle diffusion at a later stage.

\section{ACKNOWLEDGEMENTS}

The authors acknowledged the financial support from Gachsaran Branch of Islamic Azad University, Iran.

\section{REFERENCES}

1. A. Ajmal, R.A.K. Rao, S. Anwar, J. Ahmad and R. Ahmad, Bioresour Technol., 86, 147 (2003).

2. M.M. Abd El-Latif, A.M. Ibrahim and M.F. El-Kady, J. Am. Sci., 6, 276 (2010).

3. M. Ozacar and I.A. Sengil, Bioresour. Technol., 96, 791 (2005).

4. N. Dizge, C. Aydiner, E. Demirbas, M. Kobya and S. Kara, J. Hazard. Mater., 150, 737 (2008).

5. B.H. Hameed, A.A. Ahmad and N. Aziz, Desalination, 247, 551 (2009).

6. S. Sen and G.N. Demirer, Water Res., 37, 1868 (2003).

7. L. Abramian and H. El-Rassy, Chem. Eng. J., 150, 403 (2009).

8. K. Santhy and P. Selvapathy, Bioresour. Technol., 97, 1329 (2006).

9. N.K. Amin, Desalination, 223, 152 (2008).

10. G. Annadurai, L.Y. Ling and J.F. Lee, J. Hazard. Mater., 152, 337 (2008).

11. C.H. Wu, J. Hazard. Mater., 144, 93 (2007).

12. S.T. Ong, W.N. Lee, P.S. Keng, S.L. Lee, Y.T. Hung and S.T. Ha, Int. J. Phys. Sci., 5, 582 (2010)

13. A.H. Abdullah, W.W. Yuan and M.I. Yaziz, J. Phys. Sci., 21, 29 (2010).

14. S.Y. Wong, Y.P. Tan, A.H. Abdullah and S.T. Ong, Malays. J. Anal. Sci., 13, 185 (2009).

15. N. Zatar, A.A. Zuhri and N. Tayem, An-Najah Univ. J. Res. (N. Sc.), 18, 173 (2004)

16. M.R. Torres and M.C. Gutierrez, Chem. Eng. J., 156, 114 (2010).

17. R. Han, D. Ding, Y. Xu, W. Zou, Y. Wang, Y. Li and L. Zou, Bioresour. Technol., 99, 2938 (2008).

18. Y. Guo, S. Yang, W. Fu, J. Qi, R. Li, Z. Wang and H. Xu, Dyes Pigm., 56, 219 (2003)
19. F. Adam and J.H. Chua, J. Colloid Interf. Sci., 280, 55 (2004).

20. P.K. Malik, Dyes Pigm., 56, 239 (2003).

21. L. Li, J. Wang, M. Zhao, C. Cui and Y. Jiang, Food Technol. Biotechnol., 44, 441 (2006).

22. K. Yetilmezsoy and S. Demire, J. Hazard. Mater., 153, 1288 (2008).

23. R.Q. Fu, T.W. Xu and Z.X. Pan, J. Membr. Sci., 251, 137 (2005).

24. G.R. Shetty, H. Malki and S. Chellam, J. Membr. Sci., 212, 99 (2003).

25. S. Erenturk and K. Erenturk, J. Food Eng., 78, 905 (2007).

26. I. Langmuir, J. Am.Chem. Soc., 38, 2221 (1916).

27. H.M.F. Freundlich, J. Phys. Chem., 57, 385 (1906).

28. M.J. Temkin and V. Pyzhev, Acta Physiochim. URSS, 12, 217 (1940).

29. M.M. Dubinin, Chem. Rev., 60, 235 (1960).

30. M. Al-Meshragi, H.G. Ibrahim and M.M. Aboabboud, World Congress on Engineering and Computer Science WCECS, October, San Francisco, USA, p. 22 (2008).

31. M. Nameni, M.R. Alavi Moghadam and M. Arami, Int. J. Sci. Technol., 5, 161 (2008)

32. A.M. Kul and N. Caliskan, Adsorpt. Sci. Technol., 27, 85 (2009)

33. S. Lagergren, K. Svenska Vetenskapsakad. Handl., 24, 1 (1898).

34. Y.S. Ho and G. McKay, Chem. Eng. J., 70, 115 (1987).

35. W.J. Weber and J.C. Morris, Proc. Am. Soc. Civil Eng., 89, 31 (1963).

36. L. Markovska, V. Meshko, V. Noveski and M. Marinovski, J. Serb. Chem. Soc., 66, 463 (2001).

37. L.Y. Fraiji, D.M. Hayes and T.C. Werner, J. Chem. Edu., 69, 424 (1992).

38. M.G. Zuhra, M.I. Bhanger, A. Mubeena, N.T. Farah and R.M. Jamil, Chem. Eng. J., 138, 616 (2008).

39. D.L. Sparks, Soil Phys. Chem., CRC Press, Boca Raton, FL, edn. 2, p. 83 (1999).

40. M. Al-Ghouti, M.A.M. Khraisheh, M.N.M. Ahmad and S. Allen, J. Colloid Interf. Sci., 287, 6 (2005).

41. R. Sanghi and B. Bhattacharya, Color Technol., 118, 256 (2002).

42. A. Prakash, S. Solanki and P.P. Rao, Indian J. Chem. Technol., 15, 146 (2008).

43. N. Kannan and M.M. Sundaram, Dyes Pigm., 51, 25 (2001).

44. P.K. Malik, J. Hazard. Mater., 113, 81 (2004).

45. B.E. Reed and M.R. Matsumoto, Sep. Sci. Technol., 28, 2179 (1993).

46. P. Janos, P. Michalek and L. Turek, Dyes Pigm., 74, 363 (2007).

47. B. Acemioglu, Bioresour. Technol., 93, 99 (2004).

48. N. Sharma, K. Kaur and S. Kaur, J. Hazard. Mater., 163, 1338 (2009).

49. K. Porkodi and V. Kumar, J. Hazard. Mater., 143, 311 (2007).

50. R. Ahmad, J. Hazard. Mater., 171, 767 (2009).

51. N.C. Das and M. Bandyopadhyay, Appl. Clay Sci., 6, 403 (1992). 